\title{
A Time Series Analysis of the Impact of International Sporting Events on International Arrivals: Melbourne, Australia and Jamaica
}

\author{
Twila-Mae $\operatorname{Logan}^{1}$, Eritha Huntley Lewis ${ }^{1} \&$ Clive Scott $^{1}$ \\ ${ }^{1}$ Mona School of Business and Management, University of the West Indies, Mona, Jamaica \\ Correspondence: Twila-Mae Logan, PhD., Mona School of Business and Management, University of the West \\ Indies, Mona Campus, Jamaica. Tel: 876-977-3775. E-mail: twilamae.logan@uwimona.edu.jm
}

Received: March 11, 2016

Accepted: March 31, 2016

Online Published: May 25, 2016

doi:10.5539/ijef.v8n6p267

URL: http://dx.doi.org/10.5539/ijef.v8n6p267

\begin{abstract}
This study examines changes in international tourist arrivals in Melbourne, Australia after the 2006 Commonwealth Games, and tourist arrivals in Jamaica after the 2007 Cricket World Cup matches to answer the questions: do international arrivals increase as a result of hosting a large sporting event, and how long is the impact sustained over the post-event period? Using data prior to the Games, autoregressive models with independent variables were used to model these series. The differences between the actual and predicted series after the Games were attributed to shocks caused by hosting the Commonwealth Games. In the Australian case, the results indicate that after the Games, international arrivals were marginally higher than before the Games. In the Jamaican case, the data indicate that while there was an increase in international tourist arrivals for the event, the international tourist arrivals from non-traditional countries increased after the World Cup Cricket matches.
\end{abstract}

Keywords: commonwealth games, world cup cricket, international tourist arrivals, Melbourne Australia, Jamaica

\section{Introduction}

Over the last few decades, tourism has become a key driver of socio-economic progress. As such, tourism contributed US\$1.5 trillion in export earnings and 9\% of the global GDP in 2014 (UNWTO, 2015). In particular, tourist arrivals have been boosted by people travelling to attend sporting events. According to Fourie and Santana-Gallego (2011), some of these events attract tourists from all over the world, permanently changing the host cities or countries, and putting the spotlight on new tourism destinations. The possibility of increased tourist arrivals, increased revenue and other attending socio-economic benefits provide an impetus for destinations to compete to host these sporting events. As such, this study will examine the impact of the Commonwealth Games 2006 on Melbourne, Australia and the ICC World Cup 2007 on Jamaica to determine the impact that these events had on the destination.

\subsection{Tourism Sector Performance - Australia \& Jamaica}

A comparison of the two destinations under review present distinct differences in terms of their tourism industry and experience in hosting sporting events. Tourism's contribution to Australia's GDP was AUD\$31,495 million in 2010-2011 (Note 1) as compared to AUD \$18,560 million in 1997-1998 (Note 2). This represents an average annual growth rate of $4.2 \%$. However, the Australian economy grew faster over the same period, resulting in tourism's share of GDP falling from $3.1 \%$ in $1997-1998$ to $2.5 \%$ in $2010-2011$. Similarly employment in the tourism sector grew by an average annual rate of $1.6 \%$, but fell from $4.9 \%$ of total employment in $1997-98$ to $4.5 \%$ in 2010-11. Domestic tourism dominated the tourism sector, accounting for more than $70 \%$ of the total direct tourism GDP in 2010-2011. (Australian Bureau of Statistics, 2010-2011). On the other hand, tourism's hotels and restaurants' gross contribution to Jamaica's GDP was JA\$64,354 million in 2011 (Note 3), a decline when compared to JA \$64,794 million in 2009 (Note 4). Although the industry declined by about $0.77 \%$ per year, this is less than the $1.4 \%$ per year decline in the average GDP of the country for the period 2009 to 2011 (STATIN, 2009-11).

Total tourism receipts for Australia in the five year period before the Commonwealth Games (2001-2005) was $2.55 \%$ of GDP, while tourist expenditure was $1.74 \%$ of GDP. By contrast, total tourism receipts for Jamaica 2002-2005 was $17.15 \%$ of GDP, with expenditure amounting to $2.9 \%$ of GDP. In examining the receipts for the 
period after the sporting events, however, Australia's tourism receipts for 2007-2010 increased to 3.57\%, while Jamaica's tourism receipts increased to $17.47 \%$ of GDP (World Bank, n.d.). Jamaica's total tourist arrivals grew consistently by an average of $3.43 \%$ in the four years following the ICC World Cup (Jamaica Tourist Board, 2010).

Australia has invested heavily in the hosting of mega sporting events ranging from the Olympic Games, the Goodwill Games and the Gay Games to the Commonwealth Games (Cashman, Toohey, Darcy, Symons, \& Stewart, 2004). Jamaica has, however, hosted a number of athletic meets and the World Netball Championships in 2003.

\subsection{Relevant Scholarship}

This paper hopes to provide additional evidence of the long term impact of major sporting events on tourist arrivals to host destinations. Specifically, the research will answer the following questions:

- Do international arrivals increase as a result of hosting large sporting event?

- How long is the impact sustained over the post-event period?

This study uses data from both the Commonwealth Games that were held in Melbourne, Australia in March 2006, and the International Cricket Council (ICC) World Cup Cricket matches that were held in Jamaica in the first quarter of 2007. These international sporting events were selected to ensure that there was a sufficiently long post-game period to analyse the impact of these events. There is no attempt to measure the overall economic impact on the city and country under review. The results of the study suggest that there was a significant increase in international arrivals during both the Commonwealth Games and the ICC World Cup. The data from Jamaica also indicates that there were significant increases in post-game arrivals from territories where Jamaica does not traditionally attract visitors.

\section{Review of Literature}

This paper draws on two strands of literature (i) the impact of arrivals due to some type of shock either the positive shock of hosting a mega sporting event including events or the negative shock of natural or man-made disasters e.g. hosting the FIFA World Cup or the terrorist attacks of September 2001 and (ii) time series models used to forecast arrivals. Below we highlight some of the related literature and studies that have been done in both areas.

\subsection{Overview of the Sporting Events - Commonwealth Games and ICC Cricket World Cup}

The British Empire Games started in 1930 in Hamilton, Canada with four hundred athletes from eleven Commonwealth nations (Note 5). The main distinguishing characteristic of the Games is that it is linked to a British imperial past (Cashman et al., 2004), members being primarily those countries which were part of the British Empire. After numerous name changes, these Games were, in 1978, officially designated as the Commonwealth Games. By this time, the Games, which had attracted almost fifteen hundred competitors from forty-six Commonwealth nations, were held every four years (except for 1942 and 1946 during World War II). In 2002, athletes with disabilities competed in a limited number of full medal events in the games that were held in Manchester, England (The Commonwealth Games Federation.).

The Insight Economics conducted a survey of the 2006 Commonwealth Games which, according to the Commonwealth Games Federation President, Michael Fennel, were "simply the best". Here we highlight a few of the performance targets that were measured. There were 2.1 million attendees, 4,500 athletes from 71 countries, and 4 billion television viewers. International visitors numbered 60,125 and interstate visitors 57,010. More importantly, $85 \%$ of Melbournians felt that the Games enhanced Melbourne's reputation. From an economic standpoint, the Gross State Product (Note 6) was $\$ 1.6$ billion and 13,584 more persons were employed than would have been the case without the Games. Finally, of particular interest for our research, $71 \%$ of the international visitors, and $67 \%$ of the interstate visitors, indicated that the games made it more likely they would return to the Australian state, Victoria (Melbourne is in the capital city of Victoria), in the future.

According to Cashman et al. (2004), the Commonwealth Games are a second-tiered sports festival that has been overshadowed by other events including the Olympic Games and the World Cups of soccer, rugby and cricket.

The International Cricket Council (ICC) World Cup Cricket matches began in England in 1975 and have been held every four years in different cricket regions - Australia and New Zealand; India and Pakistan; and South Africa, Kenya and Zimbabwe. The influence of matches has grown significantly through the years and it is expected that when the matches are held in Australia/New Zealand in 2015, there will be 14 teams, engaging about twenty percent of the world's population and more than one billion television viewers (International 


\section{Cricket Council, n.d.).}

The 2007 staging of the event in the West Indies was the first time in any sport, that a World Cup was staged in nine independent countries - Antigua and Barbuda, Barbados, Grenada, Guyana, Jamaica, St. Kitts and Nevis, St. Lucia, St. Vincent and the Grenadines, and Trinidad and Tobago, with 16 teams contesting 51 matches (Jordan, 2011). For the Caribbean, it was anticipated that the World Cup would have had a significant impact on the economic outlook of the region. While various estimates of this impact were given, more than 100,000 visitors were expected to visit in addition to the 'regular' tourist traffic, with an expected spend of US\$250,000,000 over the six weeks period (Jordan, 2011).

\subsection{Impact of Hosting Large-Scale Events}

To estimate growth in tourism when hosting mega-events Fourie and Santana-Gallego (2011) used a gravity equation model. They estimated the effects of six mega-sport events, namely the Summer and Winter Olympic Games, FIFA World Cup, Cricket World Cup, Rugby World Cup and the Lions Tour. By using bilateral tourism flows among 200 countries from 1995 to 2006, they investigated whether tourism increases when a country is hosting a mega-event. The results from their study for Olympic Games were mixed and were not always consistent with prior literature. For example, this study found that summer Olympic Games appear to increase visitor arrivals by $15 \%$ on average, but there were tremendous differences from location to location - the 2000 Summer Games in Sydney saw a 43\% increase in visitor arrivals while the 2004 Summer Games in Athens resulted in a 30\% decline in visitor arrivals. In general, for Winter Olympic Games, the overall increase in visitor arrivals was not significant. The 1998 Nagano Winter Games had significant decline in arrivals, while the 2006 Turin Winter Games saw no change in arrivals. The FIFA World Cup, Cricket World Cup, and the Lions Tour have a positive impact on tourist arrivals, while the Rugby World Cup had a negative impact on tourism. The 1998 FIFA World Cup in France and the 2002 FIFA World Cup in South Korea and Japan showed a rise in tourist arrivals of $12 \%$ and $18 \%$ respectively. The overall conclusion is that mega-sport events promote tourism, but the gain varies depending on the type of mega-event and whether the event is held during the peak season or off-season.

When examining the economic impact of hosting mega-events, like the Olympics, on trade, Rose and Spiegel (2011) suggest that the impact is statistically significant for host countries and showed an increase in trade of over $20 \%$ for countries that have hosted the Olympics. The overall results indicated that hosting the Olympics has a positive impact on trade; however countries that bid for the Olympics unsuccessfully also experience a boost in trade, when compared with countries that actually hosted the Olympics.

In their assessment of the impact of the 1992 Olympics on the tourism industry in Barcelona, Duran (2005) suggests that the Olympic event placed Barcelona on the map and led to it becoming one of Europe's main tourist destinations. Prior to 1992, Barcelona had a total of 118 hotels, providing 10,265 rooms and a total of 18,569 beds. By late 1992, the number of hotels had risen to 148 , with 13,352 rooms and a total of 25,055 beds. Four years after the Games, Barcelona reported $80 \%$ or higher occupation rates; $85 \%$ more hotel beds than in 1990; and $37 \%$ more beds than in 1992, and a total of 34,303 beds by the end of 2001. In 2001, Barcelona had approximately 8 million overnight stays $(7,969,496)$ and 3,378,635 visitors to the city. The data analysis for the period 1990-2001 shows that the number of overnight stays rose by $110 \%$ and the number of visitors by $95 \%$.

In a study of the 2006 Melbourne Commonwealth Games, Lockstone and Baum (2008) found that room rates had increased sharply for the games, but occupancy rates were $80-85 \%$ with last minute room rate discounting. In addition, the authors referenced a survey that showed a 14,000 drop in international visitor arrivals over the previous year.

Porter and Fletcher (2008) however, did not find any significant benefits to any communities that hosted sporting events, except for nominal increases in hotel prices in the short run. In other words, they argued that, after the increase in factor prices (e.g. room rates) was eliminated, there was no real increase in demand i.e. increased occupancy rates. Their study found increases in room rates of $43 \%$ during the Atlanta Summer Olympic games, and $141 \%$ room rate increase in the Salt Lake City Winter Olympics. Occupancy rates went up by only $2.9 \%$ in Atlanta and $31.6 \%$ in Salt Lake City.

Seetaram (2010) found that in the short term, international arrivals (demand) were inelastic with respect to income, measured using GDP per capita of the visitors' country, and airfares. In the long run, income elasticity was strong and positive, and airfare elasticity was negative. Prices as measured by the exchange rate between Australia and the visitors' country were elastic in both the short and long term. Other findings indicated that both the Asian Financial Crisis in 1997, and the September $11^{\text {th }} 2001$ terrorist attack, had a negative impact on tourist arrivals. However, repeat visits were an important factor in tourist arrivals. 


\subsection{Methodological Approaches to Measure Impact}

Scott and Turco (2009) used an assessment model to examine the economic impact of consumer spending at the US Women's Open Golf Tournament in 2009. They explicitly modeled expenditure for different segments of the spectators, by subtracting expenditures that would have been made by tourists or locals who had cancelled or "run away" from the area - precisely because of the real or perceived congestion surrounding the tournament.

Assaf, Barros and Gil-Ana (2011) examined monthly tourist arrivals to Australia to determine the degree of persistence of seasonality and long run trends. The authors used fractional integration and seasonal autoregressive (AR) models and found that the arrival series are mean reverting with strong seasonal components. The use of the fractional integration models allows for differencing to be non-integer. Their model (with $\mathrm{d}<1$ ) provided better forecasts than the traditional non-stationary $(\mathrm{d}=1)$ or stationary $(\mathrm{d}=0)$ series. They concluded inter alia that (i) over-differencing may occur when using the standard Auto Regressive Integrated Moving Average (ARIMA) models and (ii) that the external shocks will take a long time to disappear (persistence) given the strong AR components. However, the long term trend is not as strong as the seasonal component.

In forecasting tourist arrivals into China from 5 countries: Australia, Canada, Germany, United Kingdom and the United States, Ayeh and Lin (2011) used an econometric model. They found inter alia strong seasonal factors in the tourist arrival series, as well as significant coefficients on the lagged arrival variables. The authors interpret these lagged variables as "the demand for China tourism being dependent on previous visits". Alternatively, this can also mean that as the tourist arrivals into China can be modeled as a mean reverting autoregressive model, as the lagged coefficients are less than one. In a similar study examining the demand for tourist arrivals in South Tyrol in northern Italy, Bida and Risso (2009) also found that the lagged number of German tourists was significant and less than one. This suggests that this series can be modeled as a mean reverting autoregressive model.

Lim and McAleer (2005) modeled tourist arrivals from Japan to Australia using standard ARIMA models for the entire sample period and for subsample periods. They argued that fundamental shifts in demographics and in the economic fortunes of Japanese tourists would significantly affect their demand for vacations in Australia, thus using only past data to forecast future demand could lead to erroneous forecasts. The authors find that a ARIMA $(4,1,4)$ was the best fitted model for entire period (first quarter) 1976-2002 (second quarter) the arrival series, while the best fit models for the two sub-periods first quarter 1976 to second quarter 1987 and third quarter 1987 to second quarter 2002 were ARIMA $(4,1,4)$ and $\operatorname{ARIMA}(3,1,2)$ respectively. The authors used $\log$ transformation of the series to convert from exponential growth to linear growth as well as to reduce the effects of outliers.

The Lagrange Multiplier Unit Root test was used by Lean and Smyth (2009) to endogenously determine if structural breaks (shocks) had occurred for tourist arrivals to Malaysia. Specifically, they looked for structural changes (intercept and slope) in the arrival series (from several different countries) due to natural disasters like the 2004 Boxing Day tsunami, the SARS scare, the Asian financial crisis, and the Bali terrorist bombings. The authors found structural breaks corresponding to different external shocks. These breaks varied from country to country, for example, the structural break for Japanese tourists occurred after the outbreak of SARS and avian flu in 2003, while the structural break for USA tourists occurred after the bombings in Kenya and Tanzania and the US state department's issuing of travel warnings for parts of Asia including Malaysia. The authors were able to reject the null hypothesis of the presence of unit root in all the arrival series at the 5\% level or lower, thus confirming that external shocks are transitory in nature. This finding is consistent with several other studies (Narayan, 2005, 2005a, 2005b, Vogelsang, 1997) and Sen (2003) on tourist arrivals quoted in their paper.

Bonham, Edmonds, and Mak (2006) utilized moving average models - vector error correction modelling (VECM), to explain the shocks to tourist arrivals in Hawaii after the terror strikes on September 11, 2001. They argued that this was a better model than the simple autoregressive integrated moving average models (ARIMA) used by other researchers. Obtaining the data before the third quarter of 2001, they predicted arrivals, out-of-sample forecasts, for the third quarter of 2001 through to the first quarter of 2005. They then used the forecasts as the pre $9 / 11$ trend and compared those to the actual arrivals. The difference, then, is a function of the external shock arising from the terrorist attacks.

Having evaluated the methods used to determine the impact of shocks, such as the hosting of large-scale events, the researchers have used this approach for the completion of this paper.

\section{Data and Methodology}

To determine if the Commonwealth Games and the ICC World Cup Cricket resulted in any change in arrival 
series, the international arrivals were modeled as an autoregressive model with growth in international arrivals as an independent variable. From the literature, for example, Assaf et al. (2011), Seetaram (2010), Lim and McAleer (2005), it was felt that international tourist arrivals would be a function of several independent variables, inter alia demographics, exchange rates, prices of airline tickets and the strength of the economy from which the international tourists came. Most of the earlier studies examined tourist arrivals between two countries: for example Japan and Australia. Here, this study examines total international tourist arrivals in to Melbourne and Jamaica. Thus, it can be argued that the composite worldwide international arrivals would capture overall trends in international tourism, especially worldwide economic conditions. The vector autoregressive moving average process with exogenous regression (VARMAX) procedure from the SAS statistical packages was used to estimate the model parameters for the time series.

\subsection{Data}

Monthly international tourist arrivals in Melbourne, Australia were obtained from the Australian Bureau of Statistics Time Series Workbook for the period January 2003 to August 2010. The data for growth in worldwide tourist arrivals were obtained from the UN World Tourism Organization (UNWTO) Tourist Barometer report. Although it was possible to obtain a longer series for the Melbourne data, the UNWTO Tourist Barometer series were only available from January 2003. The monthly data of international arrivals from countries that participated in the ICC World Cup Cricket were obtained from the Jamaica Tourist Board Annual Travel Statistics reports. The period assessed for Jamaica was January 2001 to October 2011 and was based on the data available for the Jamaica Tourist Board.

The autoregressive AR $(1,6)$ model with an independent variable was selected to model the time series model for the Melbourne data. Several other models at different lags were estimated, using the log of arrivals in Melbourne, but these did not produce any significantly better results so only the AR model using the international arrivals in Melbourne as the dependent variable and worldwide tourist arrivals as the independent variable was used.

In examining the impact of international tourist arrivals in Jamaica following the ICC World Cup Cricket competition in 2007, we argue that any changes in arrivals that can be attributed to the hosting of the cricket competition should be seen in the arrivals from cricket playing nations as opposed to the general population of international tourists. Thus, data on the arrivals from the following countries/regions: the United Kingdom, Commonwealth Caribbean (including Guyana), India \& Pakistan, Australia, New Zealand, and Africa, was extracted. We combined India \& Pakistan since in the earlier years the data combined arrivals from India and Pakistan. The researchers would have preferred to have data from Kenya, Zimbabwe and South Africa as single countries, but the data source collated all the African countries as one. These arrival series were modeled as AR models up to lag 12 and a linear trend using the VARMAX procedure.

The AR models derived from the VARMAX procedures were used to forecast the series for the period January 2006 to August 2010 for Melbourne and the period February 2007 to October 2011 for Jamaica. Like Bonham et al. (2006), it was assumed that the predicted series represented the international tourist arrivals in Melbourne and Jamaica had the Commonwealth games and the World Cup cricket matches not occurred. Thus, the difference between the predicted series and the actual series represents the shock to the series caused by the Games.

\section{Results}

\subsection{Melbourne, Australia}

The results from the AR $(1,6)$ model for this time series are presented in Table 1. Both AR coefficients are less than one and statistically significant, signifying a mean reverting series.

Table 1. Autoregressive model for international tourist arrivals to Melbourne, with growth in world-wide tourist arrivals (Intgrowth) as the dependent variable

\begin{tabular}{lccccc}
\hline Variable & DF & Estimate & Standard Error & t Value & Pr $>|\mathbf{t}|$ \\
\hline Intercept & 1 & 85392.00 & 13656 & 6.25 & 0.0001 \\
Intgrowth & 1 & 797.89 & 361.22 & 2.21 & 0.0362 \\
AR1 & 1 & 0.36 & 0.12 & 2.98 & 0.0062 \\
AR6 & 1 & -0.53 & 0.11 & -5.01 & 0.0001 \\
$\mathbf{N}$ & 36 & & & & \\
$\mathbf{R}^{2}$ & & $72.5 \%$ & & & $0.7494 ; 0.5412$ \\
Durbin-Watson & & 1.66 & & & \\
\hline
\end{tabular}


The absolute value of the AR coefficients is not close to zero, so shocks to this series should not dissipate too quickly over time. This model explained about $72 \%$ of the international arrivals with a $\mathrm{p}$ value for the model being less than 0.0001 . The $p$ values of the Durbin-Watson statistics were 0.7494 and 0.5412 , suggesting that there are no positive or negative autocorrelations in the final model at $5 \%$ significance level. The coefficient on the worldwide international tourist arrivals was positive and significant with a p-value less than 5\%.

Figure 1 depicts the actual and forecasted arrivals with the 95\% upper and lower bounds.

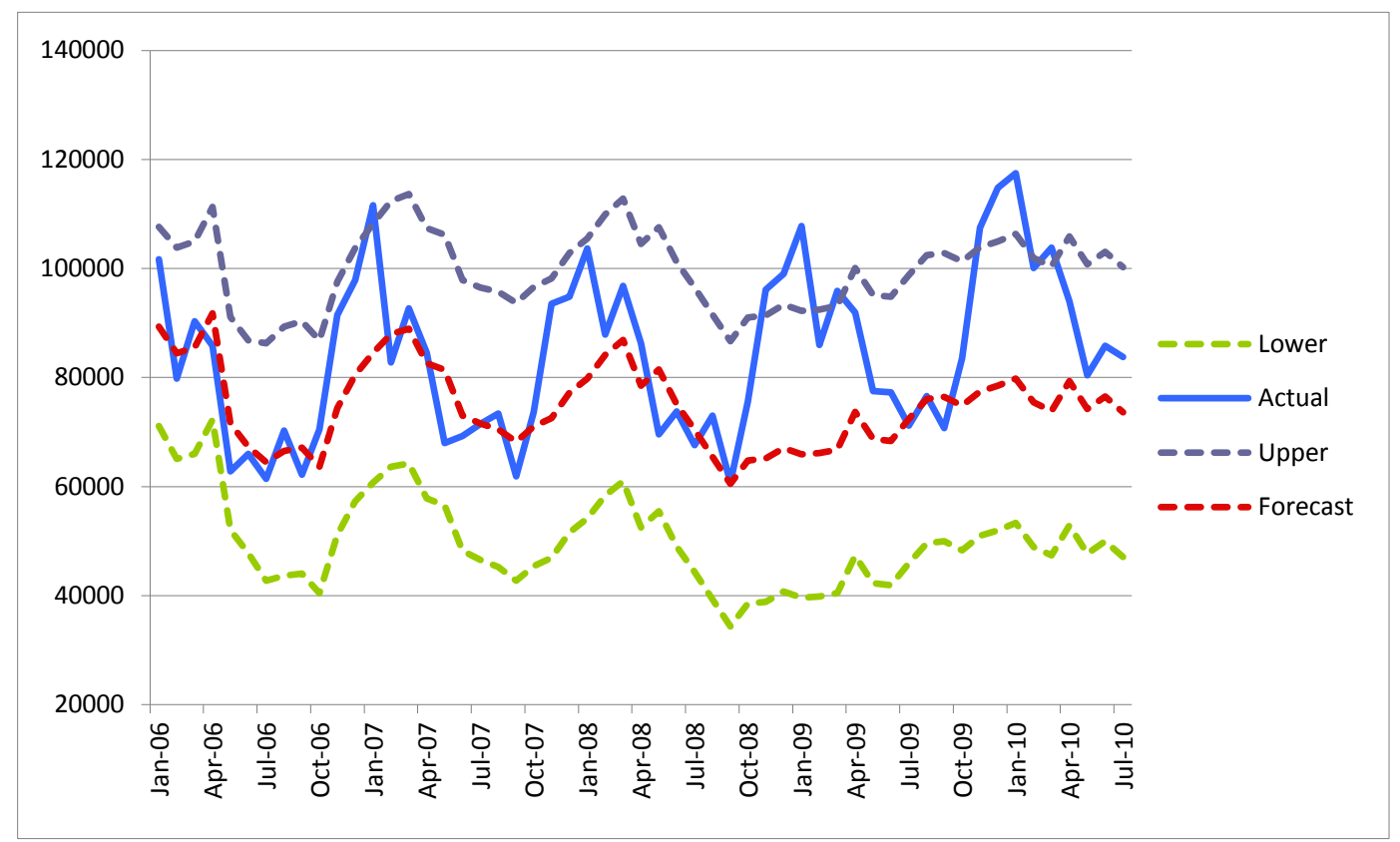

Figure 1. Actual and predicted international arrivals January 2006 through July 2010

The forecast series is represented by the dashed line and the actual arrivals by the solid line. The dotted lines represent the upper and lower bounds of the $95 \%$ confidence interval for the predicted series.

The actual and predicted series tracked very closely for 2006, thereby suggesting that the Games had not produced a very large increase in tourist arrivals. In subsequent years, 2007 to late 2008, the actual series tracked higher than the predicated series, especially during the high seasons. However, the actual arrivals were still mostly within the 95\% confidence interval of the predicted series. Beginning in September 2008, the actual series and the predicted series deviated substantially with the actual arrivals falling outside the $95 \%$ confidence interval during the high season.

\subsection{Jamaica}

Tables 2-8 present the results of the VARMAX regressions. The model was derived using data from January 2001 through to January 2007, since the cricket competition began in February 2007.

Table 2 presents the model for arrivals from all countries which serves as the base case for the analyses from the cricket playing nations. This model provided a very fit with $\mathrm{R}^{2}$ of $89 \%$, significant and positive trend indicating increasing international tourist arrivals over the period. As expected the AR coefficients at lags 1, 3, 6, 9 and 12 were statistically significant indicative of the seasonal nature of tourist arrivals. Similar to the Melbourne all the AR coefficients were less than 1 suggested mean reverting series and that shocks (positive or negative) would dissipate over time. 
Table 2. Predicted model for arrivals to Jamaica from all countries

\begin{tabular}{lrrrr}
\hline Parameter & Estimate & Standard Error & t Value & Pr $>|\mathbf{t}|$ \\
\hline CONSTANT* & 8.75378 & 5.13139 & 1.71 & 0.0946 \\
TREND ** & 0.00493 & 0.00229 & 2.16 & 0.0363 \\
AR1* & 0.22119 & 0.12196 & 1.81 & 0.0761 \\
AR2 & -0.01054 & 0.12688 & -0.08 & 0.9342 \\
AR3*** & -0.34677 & 0.12558 & -2.76 & 0.0082 \\
AR4 & 0.19884 & 0.12896 & 1.54 & 0.1298 \\
AR5 & -0.00204 & 0.13134 & -0.02 & 0.9877 \\
AR6** & -0.32133 & 0.12836 & -2.50 & 0.0158 \\
AR7 & 0.13342 & 0.12761 & 1.05 & 0.3011 \\
AR8 & 0.01124 & 0.12949 & 0.09 & 0.9312 \\
AR9*** & -0.34154 & 0.12528 & -2.73 & 0.0090 \\
AR10 & 0.08950 & 0.12657 & 0.71 & 0.4830 \\
AR11 & 0.07662 & 0.12758 & 0.60 & 0.5510 \\
AR12*** & 0.52965 & 0.12117 & 4.37 & 0.0001 \\
R2 & $89 \%$ & & & \\
F & $27.99 * * *$ & & & \\
DW & $1.42^{+}$ & & & \\
\hline
\end{tabular}

Note. *significant at $10 \%$; **significant at $5 \%$; $* * *$ significant at $1 \% ;{ }^{+}$significant at $10 \%$ for autocorrelation.

Table 3. Predicted model for arrivals to Jamaica from the Commonwealth Caribbean

\begin{tabular}{lrrrr}
\hline Parameter & Estimate & Standard Error & $\mathrm{t}$ Value & $\operatorname{Pr}>|\mathrm{t}|$ \\
\hline CONSTANT*** & 18.54400 & 6.31842 & 2.93 & 0.0051 \\
TREND*** & 0.01233 & 0.00390 & 3.16 & 0.0027 \\
AR1 & -0.10025 & 0.11476 & -0.87 & 0.3868 \\
AR2 & -0.18164 & 0.11769 & -1.54 & 0.1295 \\
AR3* & -0.20803 & 0.11551 & -1.80 & 0.0781 \\
AR4 & -0.11701 & 0.11547 & -1.01 & 0.3161 \\
AR5 & -0.12017 & 0.11301 & -1.06 & 0.2930 \\
AR6** & -0.25405 & 0.10822 & -2.35 & 0.0232 \\
AR7 & -0.15194 & 0.11006 & -1.38 & 0.1739 \\
AR8* & -0.19802 & 0.11274 & -1.76 & 0.0855 \\
AR9* & -0.19370 & 0.10924 & -1.77 & 0.0827 \\
AR10** & -0.29656 & 0.11113 & -2.67 & 0.0104 \\
AR11 & -0.03189 & 0.11481 & -0.28 & 0.7824 \\
AR12*** & 0.52867 & 0.11404 & 4.64 & 0.0001 \\
R2 & $79 \%$ & & & \\
F & $13.46 * * *$ & & & \\
DW & 2.11 & & & \\
\hline
\end{tabular}

Note. *significant at $10 \%$; **significant at $5 \%$; ***significant at $1 \%$.

Table 4. Predicted model for arrivals to Jamaica from United Kingdom

\begin{tabular}{lrrrr}
\hline Parameter & Estimate & Standard Error & $\mathbf{t}$ Value & $\mathbf{P r}>|\mathbf{t}|$ \\
\hline CONSTANT & 3.36073 & 2.82463 & 1.19 & 0.2401 \\
TREND & 0.00219 & 0.00183 & 1.20 & 0.2366 \\
AR1 & 0.07713 & 0.11032 & 0.70 & 0.4879 \\
AR2 & 0.08133 & 0.10754 & 0.76 & 0.4532 \\
AR3 & 0.14039 & 0.10518 & 1.33 & 0.1884 \\
AR4* & 0.18693 & 0.10297 & 1.82 & 0.0759 \\
AR5 & 0.16112 & 0.10632 & 1.52 & 0.1364 \\
AR6 & -0.06760 & 0.10831 & -0.62 & 0.5355 \\
AR7 & 0.00097 & 0.10983 & 0.01 & 0.9930 \\
\hline
\end{tabular}




\begin{tabular}{|c|c|c|c|c|}
\hline AR8 & -0.05757 & 0.10585 & -0.54 & 0.5891 \\
\hline AR9** & -0.24253 & 0.10485 & -2.31 & 0.0251 \\
\hline AR10* & -0.18498 & 0.10806 & -1.71 & 0.0935 \\
\hline AR11 & -0.11124 & 0.11083 & -1.00 & 0.3207 \\
\hline AR12**** & 0.65475 & 0.11219 & 5.84 & 0.0001 \\
\hline $\mathbf{R} 2$ & $71 \%$ & & & \\
\hline $\mathbf{F}$ & $9.03 * * *$ & & & \\
\hline DW & 1.45 & & & \\
\hline
\end{tabular}

Note. *significant at 10\%; **significant at $5 \%$; ***significant at $1 \%$.

Table 5. Predicted model for arrivals to Jamaica from India/Pakistan

\begin{tabular}{lrrrr}
\hline Parameter & Estimate & Standard Error & $\mathrm{t}$ Value & $\operatorname{Pr}>|\mathrm{t}|$ \\
\hline CONSTANT & 2.29515 & 1.71116 & 1.34 & 0.1863 \\
TREND & 0.00123 & 0.00299 & 0.41 & 0.6830 \\
AR1 & 0.08416 & 0.13592 & 0.62 & 0.5388 \\
AR2 & 0.02829 & 0.13449 & 0.21 & 0.8343 \\
AR3 & 0.09509 & 0.12971 & 0.73 & 0.4671 \\
AR4 & -0.04394 & 0.13172 & -0.33 & 0.7401 \\
AR5 & 0.08866 & 0.13186 & 0.67 & 0.5046 \\
AR6 & 0.03287 & 0.13027 & 0.25 & 0.8019 \\
AR7 & -0.09241 & 0.13190 & -0.70 & 0.4870 \\
AR8 & -0.00281 & 0.12930 & -0.02 & 0.9828 \\
AR9 & -0.20845 & 0.13148 & -1.59 & 0.1196 \\
AR10 & -0.05403 & 0.13170 & -0.41 & 0.6835 \\
AR11 & 0.15591 & 0.13446 & 1.16 & 0.2521 \\
AR12** & 0.29756 & 0.13531 & 2.20 & 0.0328 \\
R2 & $22 \%$ & & & \\
F & 1.02 & & & \\
DW & 1.89 & & & \\
\hline
\end{tabular}

*significant at $10 \% ; * *$ significant at $5 \% ; * *$ significant at $1 \%$.

Table 6. Predicted model for arrivals to Jamaica from Australia

\begin{tabular}{lrrrr}
\hline Parameter & Estimate & Standard Error & $\mathrm{t}$ Value & $\operatorname{Pr}>|\mathrm{t}|$ \\
\hline CONSTANT* & 3.91070 & 2.00998 & 1.95 & 0.0577 \\
TREND & 0.00252 & 0.00273 & 0.92 & 0.3612 \\
AR1 & 0.19426 & 0.14145 & 1.37 & 0.1762 \\
AR2 & 0.15404 & 0.13946 & 1.10 & 0.2750 \\
AR3 & -0.16326 & 0.14346 & -1.14 & 0.2609 \\
AR4 & -0.05531 & 0.14632 & -0.38 & 0.7071 \\
AR5 & 0.13794 & 0.14600 & 0.94 & 0.3496 \\
AR6 & -0.00263 & 0.14460 & -0.02 & 0.9856 \\
AR7 & -0.17879 & 0.14439 & -1.24 & 0.2218 \\
AR8 & -0.06671 & 0.14700 & -0.45 & 0.6521 \\
AR9 & 0.05889 & 0.14623 & 0.40 & 0.6890 \\
AR10 & 0.07029 & 0.14284 & 0.49 & 0.6249 \\
AR11 & -0.22882 & 0.14235 & -1.61 & 0.1147 \\
AR12* & 0.26444 & 0.14037 & 1.88 & 0.0658 \\
R2 & $21 \%$ & & & \\
F & 0.97 & & & \\
DW & $1.94^{+}$ & & & \\
\hline
\end{tabular}

*significant at $10 \%{ }^{+}$significant at $1 \%$ for autocorrelation. 
Table 7. Predicted model for arrivals to Jamaica from Africa

\begin{tabular}{lrrrr}
\hline Parameter & Estimate & Standard Error & $\mathrm{t}$ Value & $\operatorname{Pr}>|\mathrm{t}|$ \\
\hline CONSTANT* & 5.37756 & 2.72770 & 1.97 & 0.0546 \\
TREND & -0.00191 & 0.00320 & -0.60 & 0.5528 \\
AR1 & 0.05120 & 0.13437 & 0.38 & 0.7049 \\
AR2 & 0.16195 & 0.13701 & 1.18 & 0.2431 \\
AR3 & -0.14465 & 0.13666 & -1.06 & 0.2952 \\
AR4 & -0.20841 & 0.13666 & -1.52 & 0.1340 \\
AR5 & -0.00098 & 0.13814 & -0.01 & 0.9943 \\
AR6 & -0.10683 & 0.13531 & -0.79 & 0.4337 \\
AR7 & -0.08364 & 0.13508 & -0.62 & 0.5388 \\
AR8 & -0.06744 & 0.13806 & -0.49 & 0.6275 \\
AR9 & -0.10263 & 0.12822 & -0.80 & 0.4275 \\
AR10 & -0.13424 & 0.12867 & -1.04 & 0.3022 \\
AR11 & 0.05554 & 0.13123 & 0.42 & 0.6741 \\
AR12*** & 0.36908 & 0.13058 & 2.83 & 0.0069 \\
R2 & $38 \%$ & & & \\
F & $2.21 * *$ & & & \\
DW & 1.97 & & & \\
\hline
\end{tabular}

*significant at $10 \%$; * significant at $5 \% ; * * *$ significant at $1 \%$.

Table 8. Predicted model for arrivals to Jamaica from New Zealand

\begin{tabular}{lrrrr}
\hline Parameter & Estimate & Standard Error & $\mathrm{t}$ Value & $\operatorname{Pr}>|\mathrm{t}|$ \\
\hline CONSTANT*** & 7.97251 & 2.56246 & 3.11 & 0.0032 \\
TREND & 0.00090 & 0.00435 & 0.21 & 0.8379 \\
AR1 & -0.09102 & 0.14574 & -0.62 & 0.5353 \\
AR2 & -0.21838 & 0.14548 & -1.50 & 0.1400 \\
AR3 & -0.07838 & 0.14836 & -0.53 & 0.5998 \\
AR4 & -0.12765 & 0.14640 & -0.87 & 0.3877 \\
AR5 & -0.21732 & 0.14630 & -1.49 & 0.1441 \\
AR6 & -0.17628 & 0.14850 & -1.19 & 0.2412 \\
AR7 & -0.16351 & 0.14651 & -1.12 & 0.2701 \\
AR8 & -0.16989 & 0.14899 & -1.14 & 0.2599 \\
AR9 & -0.10401 & 0.15036 & -0.69 & 0.4925 \\
AR10 & -0.11882 & 0.15150 & -0.78 & 0.4368 \\
AR11 & -0.18842 & 0.15197 & -1.24 & 0.2212 \\
AR12 & 0.04097 & 0.15357 & 0.27 & 0.7908 \\
R2 & $14 \%$ & & & \\
F & 0.59 & & & \\
DW & $1.99^{+}$ & & & \\
\hline
\end{tabular}

*significant at $10 \% ; * *$ significant at $5 \%$; ***significant at $1 \% ;{ }^{+}$significant at $5 \%$ for autocorrelation.

The results were similar for the arrivals from the Commonwealth Caribbean (Table 3) and the United Kingdom (Table 4) with $\mathrm{R}^{2}$ of $79 \%$ and $71 \%$ respectively.

The model for arrivals from India/Pakistan (Table 5) and Africa (Table 7) were not as strong; $\mathrm{R}^{2}$ of $22 \%$ and $37 \%$ respectively. However, the AR (12) coefficients were significant. The models did not fit the arrivals from Australia (Table 6) and New Zealand (Table 8). There were no significant AR coefficient for New Zealand and the p-value for AR(12) coefficient was only 0.0658 for Australia.

The models estimating total arrivals, arrivals from the Commonwealth Caribbean, and the United Kingdom were highly significant with $\mathrm{R}^{2}$ greater than $65 \%$. Thus, we will have greater confidence in the forecasts obtained from these models. The models from the other regions/countries were not significant as the arrivals did not vary a lot from month to month or year to year in the period prior February 2007. Nevertheless the AR coefficients at lag 12, depicting annual seasonality, were all positive and less than 1 indicating that shocks will disappear over time. 
These coefficients were significant in all models except the New Zealand model. Figures 2-8 show the actual, forecasted arrivals with their upper and lower bounds, at the $95 \%$ confidence level.

The forecasted and actual arrivals from all countries are depicted in Figure 2. The predicted series tracked the actual series (post games) very closely, suggesting the cricket games did not significantly impact international tourist arrivals.

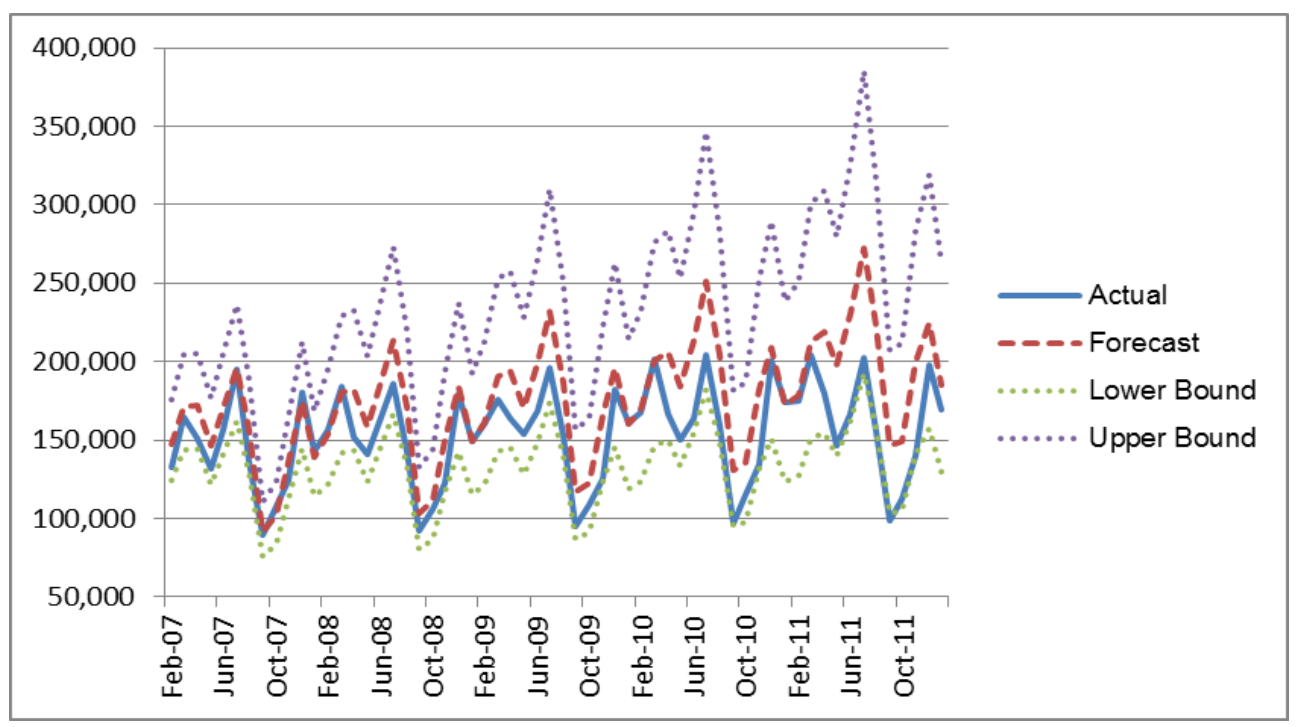

Figure 2. Visitor arrivals from all countries February 2007 to October 2011

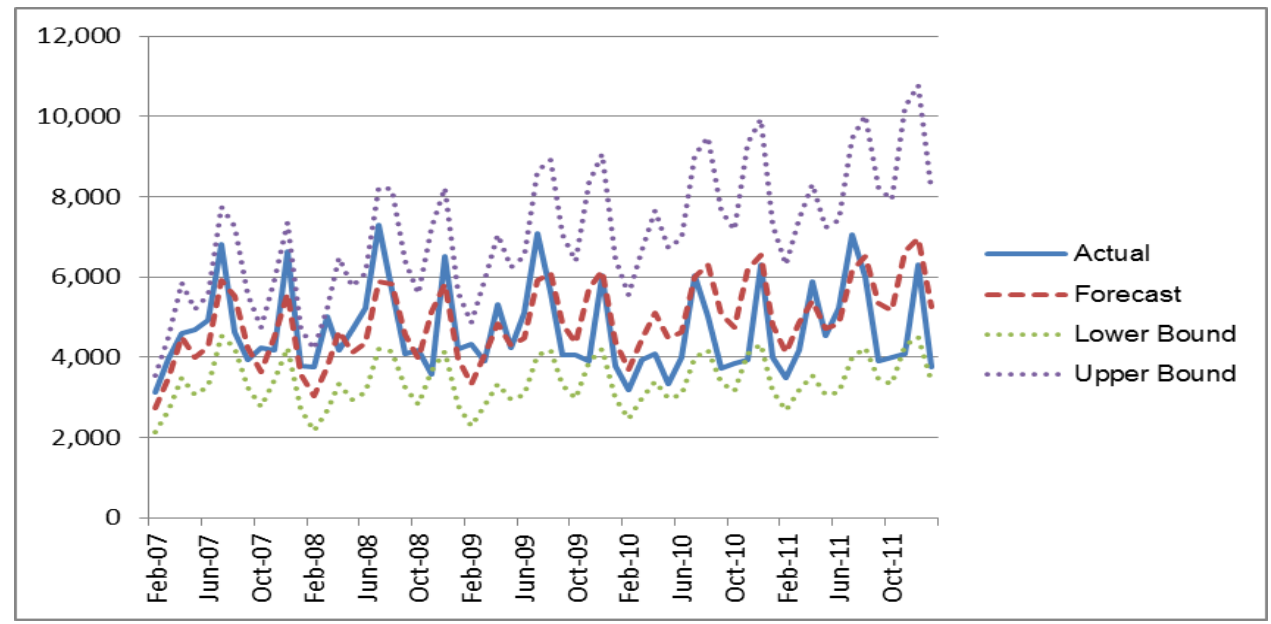

Figure 3. Visitor arrivals from commonwealth Caribbean February 2007 to October 2011

However, breaking out the arrivals from the cricket playing nations suggests that the tourist arrivals from these regions/country was different post games. (Figures 4-8).

The results from the UK model as shown in Figure 4 indicate that actual arrivals were slightly higher than the forecasted values for about 2 years, and then fell below the forecasted values. This fall-off coincided with the Great Recession of 2008 making it difficult to draw any robust conclusions. Nevertheless, the actual arrivals were all within the $95 \%$ confidence intervals that is, within the margin of error of the model. The results from the Commonwealth Caribbean model, suggest slightly higher arrivals, but this effect dissipated by mid to late 2009 (about 30 months later). Again the higher arrivals in the period just after the matches were within the margin of error of the model (see Figure 3). 


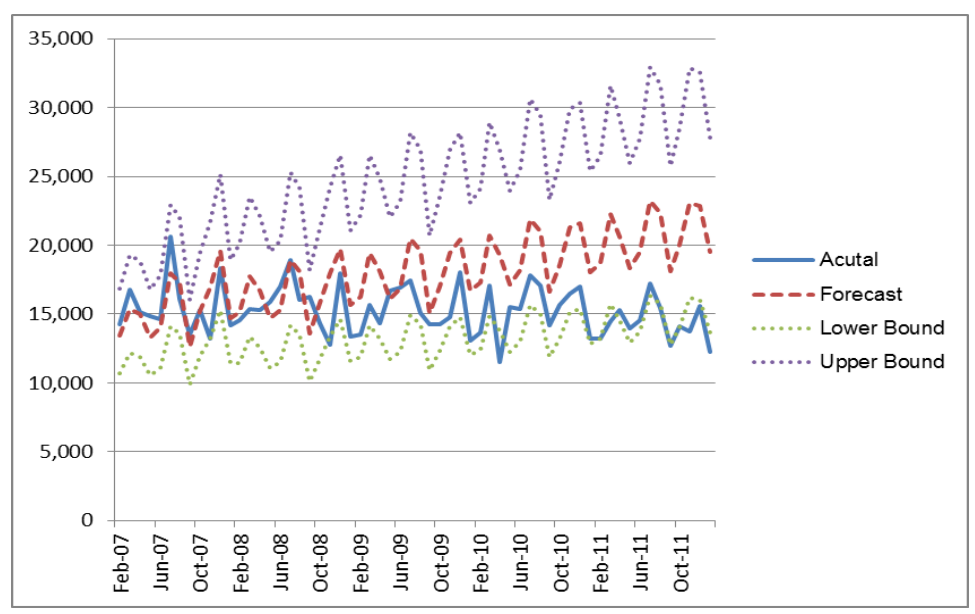

Figure 4. Visitor arrivals from United Kingdom February 2007 to October 2011

The actual tourist arrivals from India/Pakistan as seen in Figure 5, showed a significant increase at the time of the games. The actual arrivals were higher than forecasted for the entire study (up to the end of 2011) and during certain periods, the actual arrivals were higher than the 95\% upper bound, suggesting that during these periods the arrivals were significantly higher than predicted.

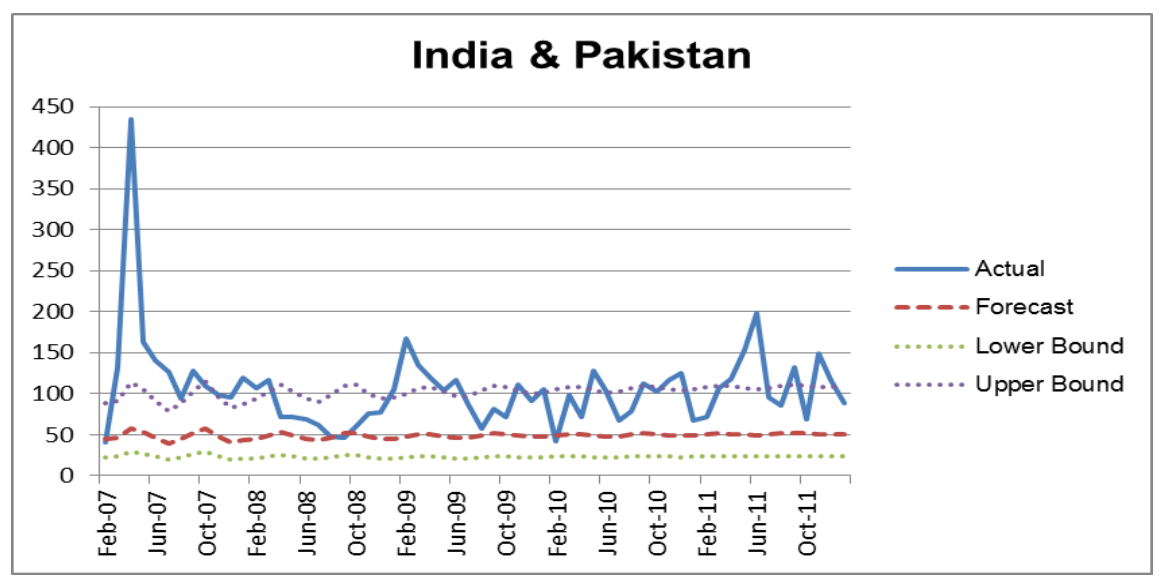

Figure 5. Visitor arrivals from India \& Pakistan February 2007 to October 2011

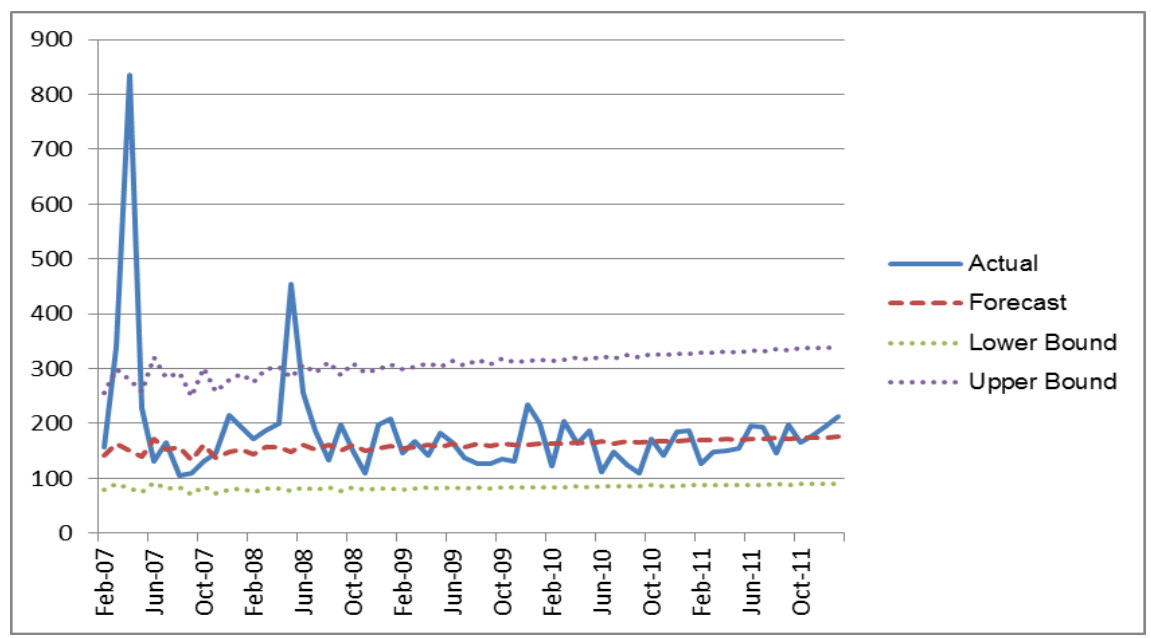

Figure 6. Visitor arrivals from Australia February 2007 to October 2011 
The results from Australia and New Zealand (Figures 6 and 7) indicates that the arrivals from these regions appear to be higher and, in some instances, significantly higher that the forecasted values. The effects of the competition appear to dissipate after 2009/2010 for Australia and New Zealand. Note, the models for these regions were not strong models (weak $\mathrm{R}^{2}$ and no significant AR coefficients) so the $95 \%$ confidence intervals are wide.

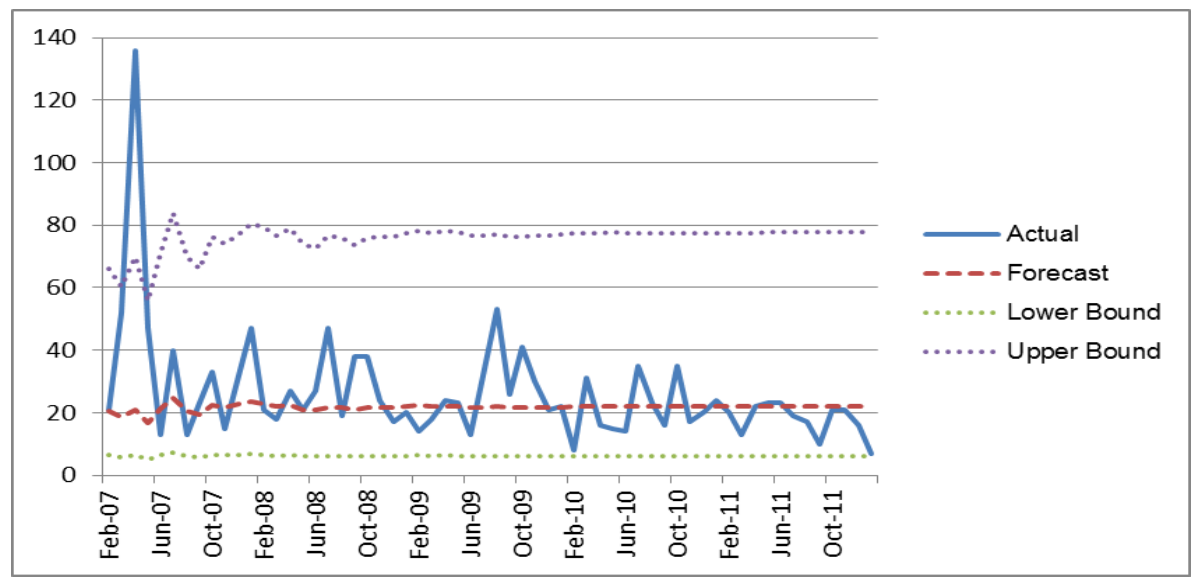

Figure 7. Visitor arrivals from New Zealand February 2007 to October 2011

Finally, the arrivals from Africa, as illustrated in Figure 8, trended above forecast but all data points were within the $95 \%$ confidence bounds.

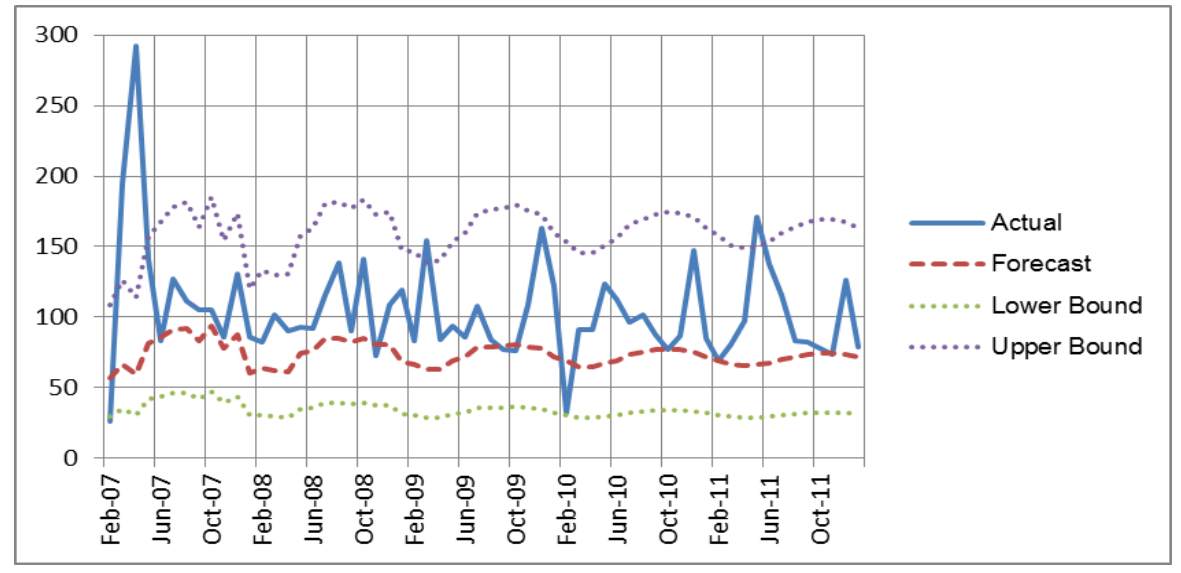

Figure 8. Visitor arrivals from Africa February 2007 to October 2011

Overall, it does appear, as if the arrival series after the cricket matches are different to that of the pre-cricket competition series for selected countries/regions (Figures 3-8) when compared with arrivals from all countries (Figure 2).

\section{Discussion}

The data presented showed mixed results in terms of the impact of the sporting events under review for Melbourne and Jamaica. For Melbourne, the actual and predicted series tracked very closely for 2006. Despite there being an increase in arrivals at the time of the Games in March 2006, the results suggest that the Games had not produced a significant increase in tourist arrivals. This is followed by the decline in arrivals immediately after the Games occurred, with a fall-off in arrivals between May and September 2006. Any increase received was sustained through the second quarter of 2008. This is consistent with Lockstone and Baum (2008), who found a 14,000 drop in arrivals about the time the Games took place. This lack of increase in arrivals is also 
consistent with other studies, for example, Scott and Turco (2009) which suggest that some visitors shy away from vacation spots during periods of intense activity. Similarly, there was also no significant effect in Jamaica, based on arrivals from the United Kingdom and The Commonwealth Caribbean (including Guyana).

In subsequent years, 2007 to late 2008, the actual series tracks higher than the predicated series for Melbourne, especially during the high seasons. This could indicate that international tourist arrivals in Melbourne increased over the ensuing eighteen months as a result of the positive exposure from the Commonwealth Games. This was also evident in the overall results for Jamaica, though the results varied among the countries under review. For the Commonwealth Caribbean (including Guyana), Australia, New Zealand and Africa visitor arrivals trended higher than forecasted immediately after the World Cup, but there were declines from the United Kingdom, India and Pakistan in 2008. By 2009, there is evidence of an overall decline in tourist arrivals from the markets under review compared to the forecast.

Beginning in September 2008, the actual series and the predicted series deviated substantially for Melbourne with the actual arrivals rising above the $95 \%$ confidence interval during the high season. The analysis was complicated by the Great Recession of 2008, the start of the worst financial market decline since the Great Depression of the 1930s, thus it was difficult to make definite statements about the long run impact of the Commonwealth Games after the $3^{\text {rd }}$ quarter of 2008. Even though the actual worldwide tourism arrivals declined after 2008, the actual series trended higher than the predicted series for Melbourne.

While the Great Recession may be a contributing factor to the general decline in international tourist arrivals it appears that the impact of the sporting events may have been sustained in Melbourne. For Melbourne, the actual arrivals in the peak season continued to trend above the forecast for 2009 and 2010. Jamaica experienced a slight deviation, with the actual arrivals trending below the forecast from 2009 to 2011 . When the data is disaggregated however, it shows that the performance varied among countries under review. For the Commonwealth Caribbean, arrivals trended higher than forecasted for 2008 and were consistent with the forecast for 2009. By 2010, however, the overall actual and predicted series deviated with arrivals falling below the forecast. This may indicate that the impact of hosting the World Cup Cricket may have dissipated by this time. Arrivals from Australia and New Zealand fluctuated within the period under review. There, therefore, appears to be no lasting impact of the event on arrivals from the two destinations. For India and Pakistan and Africa, however, while there were declines consistent with the forecast in 2008 and 2010, arrivals continued to trend above the forecast into 2011. This indicates that the event had a greater impact on tourist arrivals from the non-traditional markets. It, therefore, appears as if the effects of the competition are more significant for the countries/regions where Jamaica may not have a strong marketing presence.

\section{Conclusion}

The data suggest that international tourist arrivals in Melbourne can be modeled as an autoregressive series with significant lags at one and six. The tourist arrivals in Melbourne appear, at least prior to 2008, to be highly positively correlated with trends in worldwide international tourist travel. However, international tourist arrivals in Melbourne did not fall off with the collapse of the financial market in 2008 and the subsequent world-wide recession, as did worldwide tourist arrivals. Further research may be needed to explain this phenomenon.

In contrast, Jamaica experienced higher international arrivals from the countries that participated in the World Cup Cricket matches. Given the duration of the impact or increase in tourist arrivals from the non-traditional target markets, this study has practical implication for the destination in that it may influence marketing policy. While it did not speak to the size and possible profitability of the untapped markets, this study indicates that, with targeted events and precise marketing, Jamaica may increase its tourist arrivals from these and other non-traditional markets. The researchers cannot generalize the finding to all destinations, but additional research is needed in this area to determine the reasons why the shocks were dissipated or were sustained.

\section{References}

Assaf, A. G., Barros, C., \& Gil-Alana, L. (2011). Persistence in the Short and Long Term Tourist Arrivals to Australia. Journal of Travel Research, 50(2), 213-229. http://dx.doi.org/10.1177/0047287510362787

Australian Bureau of Statistics Time Series. (2010-2011). Retrieve from www.abs.gov.au. 7/22/2015

Ayeh, J., \& Lin, S. (2011). Estimating tomorrow's tourist arrivals: forecasting the demand for China's tourism using the general-to-specific approach. Tourism and Hospitality Research, 11(3) 197-206. http://dx.doi.org/10.1177/1467358411415466
Bank of Jamaica (BOJ). (2016). Average Annual http://www.boj.org.jm/foreign_exchange/fx_rates_annual.php
Exchange Rate. Retrieved from 
Bida, J., \& Risso, W. (2009). A dynamic panel data study of the German demand for tourism in South Tyrol. Tourism and Hospitality Research, 9(4), 305-313. http://dx.doi.org/10.1057/thr.2009.15

Bonham, C., Edmonds, C., \& Mak, J. (2006). The Impact of 9/11 and other terrible global events on Tourism in the United States and Hawaii. Journal of Travel Research, 45(1), 99-110. http://dx.doi.org/10.1177/0047287506288812

Canadian Foreign Exchange Services (CFES). Yearly Average Exchange rate for Currencies. Retrieved from http://www.canadianforex.ca/forex-tools/historical-rate-tools/yearly-average-rates

Cashman, R., Toohey, K., Darcy, S., Symons, C., \& Stewart, B. (2004). When the Carnival is Over: Evaluating the outcomes of mega sporting events in Australia. Sporting Traditions, 21(1), 1-26.

Commonwealth Games Federation (n.d.). Retrieve from http://www.thecgf.com/

Duran, P. (2005). The impact of the Games on tourism: Barcelona: The legacy of the Games, 1992-2002. Barcelona: Centre d'Estudis Olímpics UAB. Retrieved from http://ceo.uab.cat/2010/docs/wp083_eng.pdf

Fourie, J., \& Santana-Gallego, M. (2011). The impact of mega-sport events on tourist arrivals. Tourism Management, 32(6), 1364-1370. http://dx.doi.org/10.1016/j.tourman.2011.01.011

$\begin{array}{lllll}\text { International Cricket } & \text { Council } & \text { (ICC). } & \text { Retrieve }\end{array}$ http://www.icc-cricket.com/cricket-world-cup/about/279/history

Jamaica Tourist Board. (2010). Tourist Stopover Arrivals by month: 2006-2010. Retrieved from http://www.jtbonline.org

Jordan, L. (2011). Staging Sporting Events: Challenges and Opportunities. In L. Jordan, B. Tyson, C. Hayle, \& D. Truly (Eds.), Sporting Event Management: The Caribbean Experience. Surrey, UK: Ashgate.

Lean, H. H., \& Smyth, R. (2009). Asian Financial Crisis, Avian Flu and Terrorist Threats: Are Shocks to Malaysian Tourist Arrivals Permanent or Transitory? Asia Pacific Journal of Tourism Research, 14(3), 301-321. http://dx.doi.org/10.1080/10941660903024034

Lee, C. (2010). The Dynamic interactions between hotel room rates and international inbound tourists: Evidence from Singapore. International Journal of Hospitality Management, 29(4), 758-760. http://dx.doi.org/10.1016/j.ijhm.2009.09.005

Lim, C., \& McAleer, M. (2005). Analyzing the Behavior Trends in Tourist Arrivals from Japan to Australia. Journal of Travel Research, 43(4), 414-421. http://dx.doi.org/10.1177/0047287505274654

Lockstone, L., \& Baum, T. (2008). Fun in the Family: Tourism and the Commonwealth Games. International Journal of Tourism Research, 10(6), 497-509. http://dx.doi.org/10.1002/jtr.701

Naryan, P. (2005). Testing the unit root hypothesis when the alternative is a trend break stationary process: An application to tourist arrivals in Fiji. Tourism Economics, 11, 351-364. http://dx.doi.org/10.5367/000000005774352971

Naryan, P. (2005a). Did Rabuka's military coups have a permanent effect or a transitory effect on tourist expenditure in Fiji: Evidence from Vogelsang's structural break test. Tourism Management, 26(4), 509-515. http://dx.doi.org/10.1016/j.tourman.2003.11.022

Naryan, P. (2005b). The structure of tourist expenditure in Fiji. Evidence from unit root structural break tests. Applied Economics, 37(10), 1157-1161. http://dx.doi.org/10.1080/00036840500109373

Porter, P. K., \& Fletcher, D. (2008). The Economic Impact of the Olympic Games: Ex Ante Predictions and Ex Post Reality. Journal of Sport Management, 22(2), 470-486.

Rose, A. K., \& Spiegel, M. M. (2011). The Olympic Effect. The Economic Journal, 121(553), 652-677. http://dx.doi.org/10.1111/j.1468-0297.2010.02407.x

Scott, A., \& Turco, D. M. (2009). Distinguishing Event Spectator Spending Profiles: Projected Impacts of the 2009 US Open Golf Championship. Sport Management International Journal, 5(1), 39-54. http://dx.doi.org/10.4127/ch.2009.5.1.39-54

Seetaram, N. (2010). Use of Dynamic Panel Cointegration Approach to Model International Arrivals to Australia. Journal of Travel Research, 49(4), 414-422. http://dx.doi.org/10.1177/0047287509346992

Sen, A. (2003). On unit-root tests when the alternative is a trend-break stationary process. Journal of Business and Economics Statistics, 21(1), 174-184. http://dx.doi.org/10.1198/073500102288618874 
Statistical Institute of Jamaica (STATIN). (2009-2011). Retrieve from http://www.statinja.gov.jm/

The Commonwealth Games Federation. (n. d.). Retrieve from www.thecgf.com/games/story.asp

The Insights Economic. (n. $\quad$ d.). Retrieve http://www.dtpli.vic.gov.au/data/assets/pdf_file/0017/222380/Final_Report_Executive_Summary.pdf

UN World Tourism Organization (UNWTO). (n. d.). Why Tourism? Retrieved from http://www2.unwto.org/content/why-tourism

UN World Tourism Organization (UNWTO). (n. d.). World Tourist Barometer. Retrieve from http://www.e-unwto.org/loi/wtobarometereng

Volgesang, T. (1997). Wald-type tests for detecting breaks in the trend function of a dynamic time series. Econometric Theory, 13, 818-849. http://dx.doi.org/10.1017/S0266466600006289

Word Bank (n. d.). World Development Indicators. Retrieved from http://databank.worldbank.org/data/reports.aspx?source=world-development-indicators

\section{Notes}

Note 1. Average annual foreign exchange rate for 2011 US $\$ 1=$ AUS $\$ 1.033$ (CFES, 2016).

Note 2. Average annual foreign exchange rate for 1998 US $\$ 1=A U S \$ 0.629$ (CFES, 2016).

Note 3. Average annual foreign exchange rate for 2011 US $\$ 1=\mathrm{J} \$ 86.09$ (BOJ, 2016).

Note 4. Average annual foreign exchange rate for 2009 US $\$ 1=J \$ 88.49$ (BOJ, 2016).

Note 5. The Commonwealth is an association of independent sovereign states from Africa, Asia, the Pacific, the Caribbean, Canada and the United Kingdom, with 2 billion people (about $30 \%$ of the world's population).

Note 6. Gross State Product is the equivalent of Gross National Product at the state level.

\section{Copyrights}

Copyright for this article is retained by the author(s), with first publication rights granted to the journal.

This is an open-access article distributed under the terms and conditions of the Creative Commons Attribution license (http://creativecommons.org/licenses/by/3.0/). 